\title{
Novel method of determining the periodontal regenerative capacity of T-PRF and L-PRF: An immunohistochemical study
}

\section{Nowa metoda określania periodontologicznego potencjału regeneracyjnego T-PRF i L-PRF - badanie immunohistochemiczne}

\author{
Hirak Shubhra Bhattacharya ${ }^{1, D-F}$, Shiva Shankar Gummaluri, ${ }^{1, A-F}$, Madhusudan Astekar ${ }^{2, C-F}$, Ram Kumar Gummaluri ${ }^{3, A-C}$ \\ 1 Department of Periodontology and Implantology, Institute of Dental Sciences, Bareilly, India \\ 2 Department of Oral and Maxillofacial Pathology and Microbiology, Institute of Dental Sciences, Bareilly, India \\ ${ }^{3}$ Department of Chemistry, MVGR College of Engineering, Chintalavalasa, India \\ A - research concept and design; $B$ - collection and/or assembly of data; $C$ - data analysis and interpretation; \\ $D$ - writing the article; $E$ - critical revision of the article; $F$ - final approval of the article
}

Address for correspondence

Madhusudan Astekar

E-mail: madhu.tanu@gmail.com

Funding sources

None declared

Conflict of interest

None declared

Received on November 1, 2019

Reviewed on January 25,2020

Accepted on January 31, 2020

Published online on June 9, 2020

Cite as

Bhattacharya HS, Gummaluri SS, Astekar M, Gummaluri RK. Novel method of determining the periodontal regenerative capacity of T-PRF and L-PRF: An immunohistochemical study. Dent Med Probl. 2020;57(2):137-144.

doi:10.17219/dmp/117721

D0I

$10.17219 / \mathrm{dmp} / 117721$

Copyright

○) 2020 by Wroclaw Medical University

This is an article distributed under the terms of the

Creative Commons Attribution 3.0 Unported License (CC BY 3.0)

(https://creativecommons.org/licenses/by/3.0/).

\section{Abstract}

Background. Platelet-rich fibrin (PRF) plays an important role in the regeneration of the lost periodontal tissues. Immunohistochemistry (IHC) is the most sensitive staining technique for the identification and localization of specific cells. There are few studies in the available literature which use IHC to compare PRF prepared from titanium and silica glass tubes.

Objectives. The aim of the study was to use IHC to evaluate and compare cells present in the PRF membrane prepared from titanium and silica glass tubes.

Material and methods. Blood was drawn from 10 healthy volunteers and PRF was prepared from titanium and silica glass tubes. Immunohistochemical staining for the localization, distribution and pattern of cells present in PRF with the CD 3, CD 15, CD 20, CD 34, CD 61, and CD 163 antibodies was carried out. A statistical analysis including the $x^{2}$ test, independent $t$-test and unpaired $t$-test was performed to determine significant differences.

Results. There were significantly more $T$ cells, B-lymphocytes and platelets, with a strongly positive staining in terms of the cell distribution and the labeling index in the T-PRF group in comparison with the L-PRF group. However, in terms of localization, a stronger positive staining was obtained with platelets in the T-PRF group and stem cells in the L-PRF group. In terms of the cell pattern, a significantly stronger positive staining was obtained by neutrophils in the L-PRF group and B-lymphocytes in the T-PRF group.

Conclusions. Titanium PRF has the edge over PRF prepared from silica glass tubes, and emerged as a better alternative for use in the field of periodontal regeneration.

Key words: immunohistochemistry, platelet-rich fibrin, periodontal regeneration, histological techniques Słowa kluczowe: immunohistochemia, fibryna bogatopłytkowa, regeneracja periodontologiczna, techniki histologiczne 


\section{Introduction}

The regeneration of the periodontium means restoring the lost form and function of tissues so that they resemble the previously existing ones. ${ }^{1}$ Various researchers have conducted studies on achieving regeneration with the help of different biomaterials. ${ }^{2}$ The use of autologous blood products started with fibrin glue as an alternative for sutures, followed by platelet-rich plasma (PRP), in which platelets, growth factors, fibrin, and leucocytes are gathered in a gel that resembles an engineered tissue, and added a new dimension to regenerative medicine. ${ }^{3}$ Due to concerns about antigenicity, a lengthy protocol and the inability of these products to deliver steady amounts of growth factors, leucocyte- and platelet-rich fibrin (L-PRF) was introduced by Choukroun et al. ${ }^{4}$ This preparation did not require anticoagulants and was easily prepared by taking $10 \mathrm{~mL}$ of blood and centrifuging it at 2,800 rpm for $12 \mathrm{~min} .{ }^{5}$ Studies such as those by Agarwal et al. ${ }^{6}$ and Pradeep et al. ${ }^{7}$ used L-PRF as an adjunct to other biomaterials, such as a demineralized freeze-dried bone allograft (DFDBA) and 1\% metformin, in the treatment of intrabony defects; they reported improvements in clinical parameters, such as a decreased pocket depth, clinical attachment level gain and increased bone fill, thus contributing to periodontal regeneration. These results were supported by a systematic review conducted by Verma et al. in 2017, in which L-PRF used as an adjunct to biomaterials yielded promising results. ${ }^{8}$

Later, to increase the number and variety of cells that get entrapped within the fibrin meshwork, researchers developed a low-speed centrifugation concept $(1,500 \mathrm{rpm}$ for $14 \mathrm{~min}$ ), which led to the development of advanced plateletrich fibrin (A-PRF). ${ }^{9}$ These PRF membranes release growth factors at a constant rate, act as a good scaffold for cellular attachment and resorb within 7-11 days. ${ }^{10}$ Still, this duration is not long enough to stimulate osteoblast cells for alveolar bone formation. Due to the prevailing controversies regarding the contamination and adverse effects of silica in either the short or long term, as O'Connell speculated, ${ }^{11}$ there was again a search for a better biomaterial. During this process, titanium has attracted researchers' attention due to its hemocompatibility, the platelet-activating nature similar to that of silica and its extensive use in the medical field. The drawbacks of L-PRF and the advantages of titanium have led to the introduction of titanium tube-prepared platelet-rich fibrin (T-PRF) by Tunalı et al. ${ }^{12}$ The preparation is similar to that of L-PRF, but medicalgrade titanium tubes are used instead of glass tubes. The membranes are formed by centrifuging $10 \mathrm{~mL}$ of blood for a period of $15 \mathrm{~min}$ at 3,500 rpm. ${ }^{12}$ In T-PRF, titanium dioxide $\left(\mathrm{TiO}_{2}\right)$ that is present on the inner surface of the tubes helps to activate platelets, which results in the formation of T-PRF. The studies conducted on rabbits revealed that T-PRF stayed at the surgical site for a period of 21 days, which was the key to periodontal tissue regeneration. ${ }^{13}$
Due to some constraints, such as a lack of surgical reentry, studying cellular distribution in the sections of the PRF membranes could play an important role in determining the activity of cells, leading to periodontal regeneration. ${ }^{14}$ As PRF is prepared from human blood, it contains various types of cells: T- and B-lymphocytes, monocytes, neutrophils, platelets, and stem/progenitor cells. ${ }^{15}$ An in vitro study by $\mathrm{He}$ et al. showed that rat osteoblasts could differentiate and proliferate when placed in PRF; these changes were investigated at different time points with regard to the release of transforming growth factor $\beta$ (TGF- $\beta$ ) and platelet-derived growth factor AB (PDGF-AB) as well as the activity of alkaline phosphatase (ALP). ${ }^{16}$ Other studies revealed the proliferation of gingival fibroblasts, preadipocytes, dental pulp stem cells, and osteoblasts in PRF. ${ }^{17}$ In their clinical applicability study, Mazor et al. detected bone-forming potential at the implantation sites 6 months after using PRF as a grafting material. ${ }^{18}$

Immunohistochemistry (IHC) plays an important role in identifying cells with their distribution in tissue, and is widely used in various fields of medicine and dentistry for establishing the final diagnosis. ${ }^{19}$ It utilizes antibody markers in the form of proteins for identifying various specific cells. The presence of various types of cells in the PRF membrane helps to stimulate macrophages present at the tissue site, which in turn encourages periodontal healing and regeneration. ${ }^{9}$ To our knowledge, no study has been conducted to compare T-PRF and L-PRF using IHC staining. Hence, the present study was aimed to evaluate and compare the distribution, staining pattern and labeling index percentage of cells present in T-PRF and L-PRF with IHC markers.

\section{Material and methods}

The study involved 10 systemically healthy volunteers (5 males and 5 females), ranging in age from 18 to 26 years, who had all given informed consent. None of them were smokers or taking any medications that would affect the functioning of platelets, other blood cells or their relative counts. Pregnant and lactating females, subjects who had any systemic diseases or who had undergone any sort of periodontal treatment within the previous 6 months were excluded. The study was performed after obtaining approval from the ethics committee of the Institute of Dental Sciences in Bareilly, India. The sample collection was carried out in the same Institute's Department of Periodontology and Implantology, whereas the histopathological and IHC analyses of the slides were done in the Department of Oral and Maxillofacial Pathology and Microbiology therein.

\section{Procedure}

We drew $20 \mathrm{~mL}$ of whole blood from the antecubital vein; from this, $10 \mathrm{~mL}$ was transferred into sterile medical glass test tubes (Borosil Glass Works Ltd., New Delhi, India) 
and $10 \mathrm{~mL}$ into medical-grade titanium tubes (Supra Alloys, Camarillo, USA). These tubes were immediately subjected to centrifugation in an R-8C centrifuge (Remi, New Delhi, India) using Choukroun's protocol ${ }^{4}$ and Tunalı's protocol $^{12}$ to obtain L-PRF from sterile medical glass test tubes and T-PRF from titanium tubes, respectively (Table 1). No adverse centrifugation rates were applied to any of the tubes. Later, the clots were placed in $10 \%$ formalin solution for fixation for up to $24 \mathrm{~h}$ to preserve the structure and prevent autolysis. Then, the samples were routinely processed as per the protocol of Bankroft et al., ${ }^{20}$ and were subjected to IHC staining with various monoclonal mouse/rabbit anti-human antibodies (Table 2) according to the protocol described by Ghanaati et al. ${ }^{9}$

\section{Immunohistochemical staining procedure}

Initially, blocks of a 4-micrometer uniform thickness were sectioned using a microtome. The sections were then deparaffinized by heating at $55-65^{\circ} \mathrm{C}$, followed by immersion in xylene for residual deparaffinization in order to prepare the sections for staining. Subsequently, each section was immersed in proteinase $\mathrm{K}$ solution for $15 \mathrm{~min}$ for antigen retrieval and washed in phosphate buffer saline (PBS) for $3 \mathrm{~min}$. Then, 3\% hydrogen peroxide was used in 2 incubations to block peroxidase, followed by washing in distilled water. A 2-hour protein block (0.05\% bovine serum albumin (BSA) in PBS) application was carried out. The slides were then washed in distilled water, followed by PBS rinses for the application of the primary antibodies - CD-3, CD-15, CD-20, CD-34, and CD-61 from Dako Denmark A/S
(Glostrup, Denmark) and CD-163 from PathnSitu Biotechnologies Pvt Ltd. (Hyderabad, India). After 2 h, excessive antibodies were removed by repeated washing in PBS and diaminobenzidine (DAB) was applied for $15 \mathrm{~min}$. Then, a horseradish peroxidase (HRP) conjugate was applied for $15 \mathrm{~min}$, followed by washing in PBS and incubation for $10 \mathrm{~min}$. Later, the slides were washed in distilled water and counter-staining was done with Mayer's hematoxylin for $10 \mathrm{~min}$. This was followed by washing under running water, and dehydration using 95\% alcohol for $10 \mathrm{~s}$, absolute alcohol 3 times for $10 \mathrm{~s}$, and finally 3 xylol dips (10 s each). Then, the slides were mounted with coverslips using a mounting medium and dried for a microscopic examination (Fig. 1,2).

Table 1. Protocols used for preparing leucocyte- and platelet-rich fibrin (L-PRF) and titanium platelet-rich fibrin (T-PRF)

\begin{tabular}{|l|c|c|}
\multicolumn{1}{|c|}{ Biomaterial } & $\begin{array}{c}\text { Speed } \\
{[\mathrm{rpm}]}\end{array}$ & $\begin{array}{c}\text { Time } \\
{[\mathrm{min}]}\end{array}$ \\
\hline L-PRF (Choukroun's protocol) & 2,800 & 12 \\
\hline T-PRF (Tunalı's M protocol) & 3,500 & 15 \\
\hline
\end{tabular}

Table 2. List of anti-human antibodies used in the study

\begin{tabular}{|lc|}
\multicolumn{1}{|c|}{ Antibody } & Identification \\
\hline CD-3 & T-lymphocytes \\
CD-15 & neutrophils \\
CD-20 & B-lymphocytes \\
CD-34 & stem/progenitor cells \\
CD-61 & platelets (platelet glycoprotein Ila) \\
CD-163 & monocytes \\
\hline
\end{tabular}

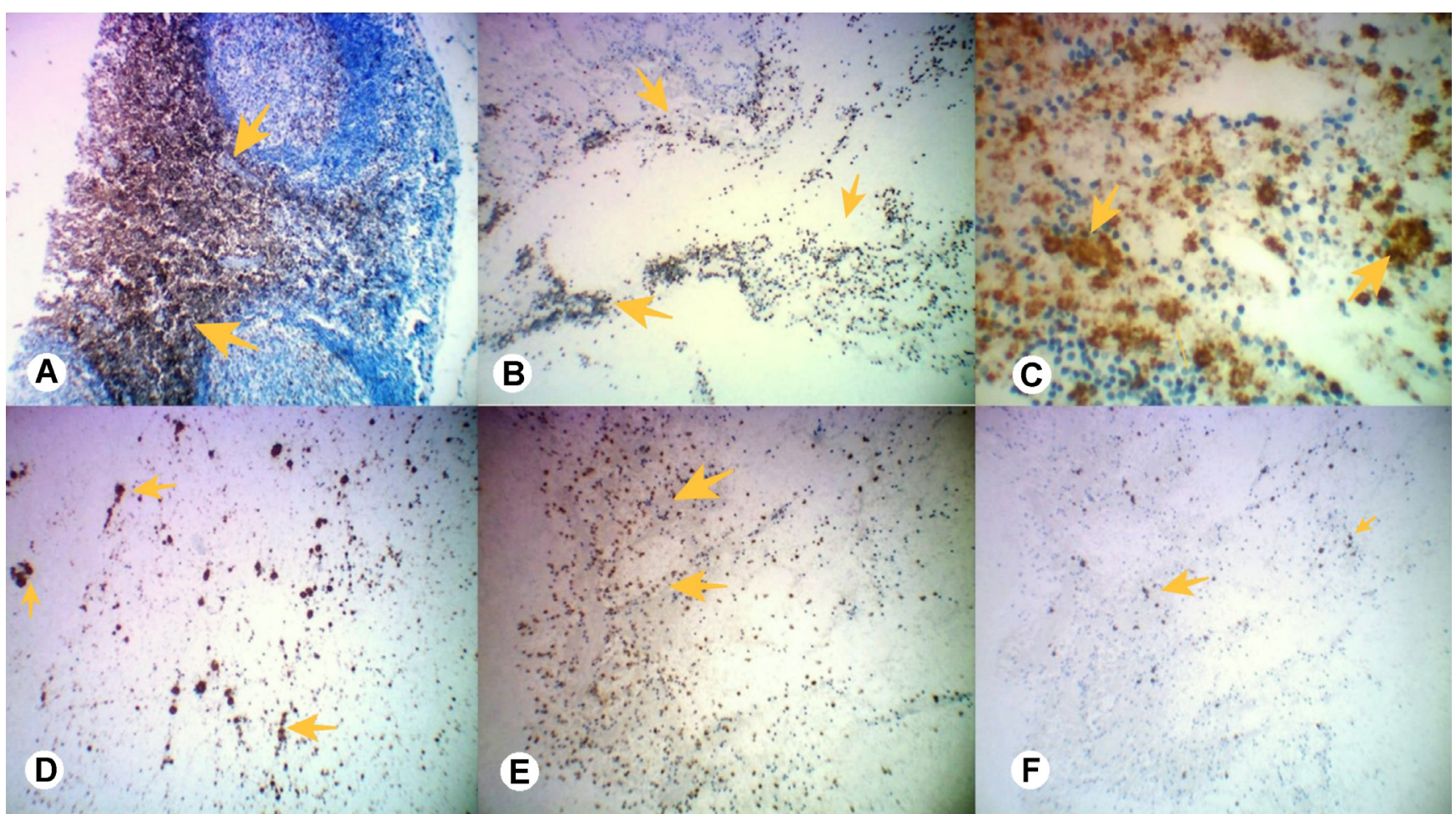

Fig. 1. Immunohistochemical images of the CD-3 (A,B), CD-15 (C,D) and CD-61 (E,F) antibody markers for both the T-PRF and L-PRF groups Yellow arrows indicate the stained cells. 


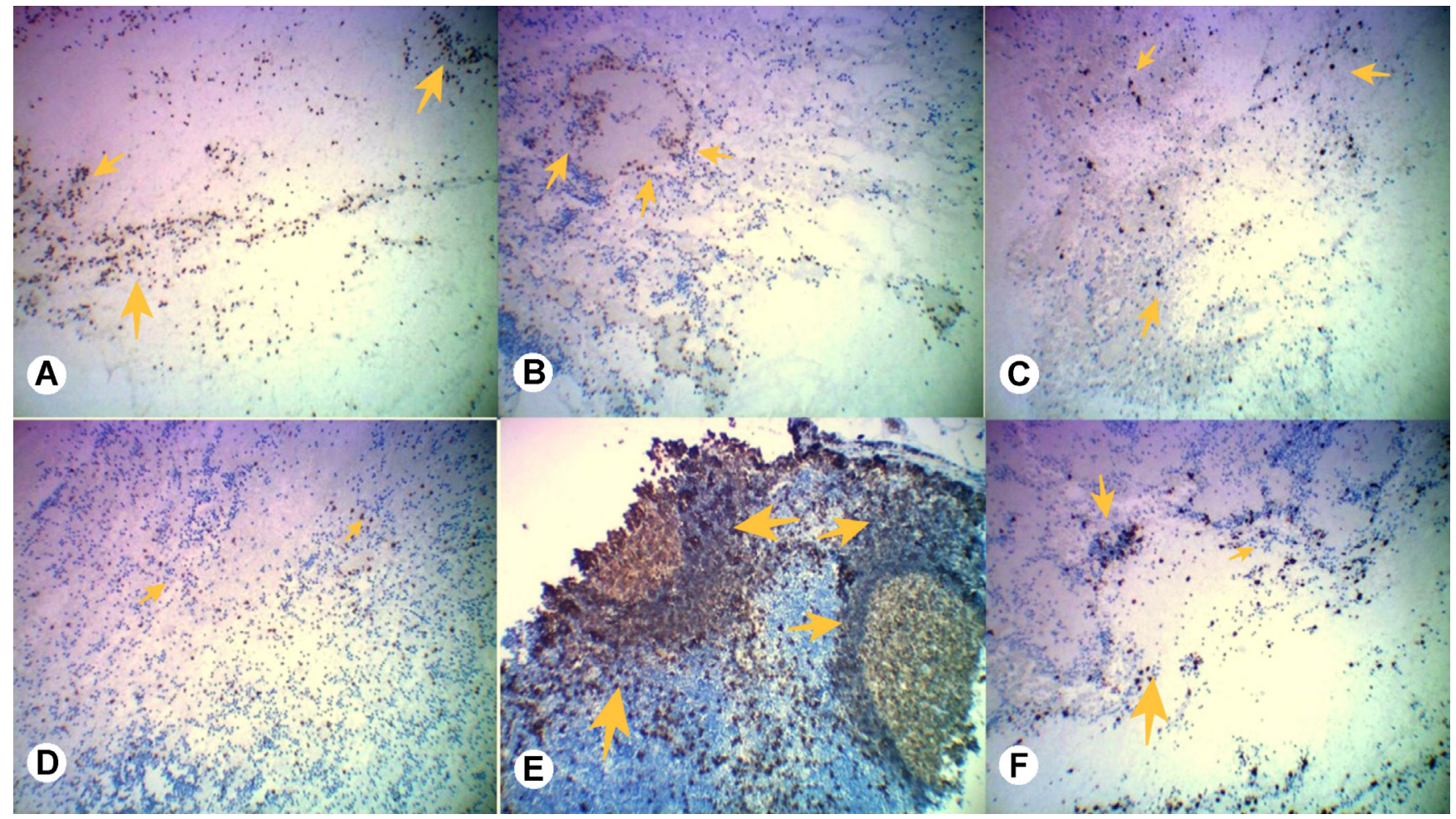

Fig. 2. Immunohistochemical images of the CD-163 (A,B), CD-34 (C,D) and CD-20 (E,F) antibody markers for both the T-PRF and L-PRF groups

Yellow arrows indicate the stained cells.

\section{Histological examination}

In order to minimize inter-examiner variability, all slides were examined by 2 experienced pathologists until consensus was reached. The fields of interest were analyzed in terms of:

- the localization of staining - whether it was cytoplasmic and/or nucleus;

- cellular distribution, as mildly positive (0-25\%), moderately positive (26-75\%) or strongly positive (76-100\%);

Table 3. Frequency distribution of the immunohistochemical $(\mathrm{IHC})$ markers in terms of the localization of cell staining

\begin{tabular}{|l|c|c|c|c|}
\multicolumn{1}{|c|}{ IHC marker } & $\begin{array}{c}\text { Study } \\
\text { group }\end{array}$ & $\begin{array}{c}\text { Cytoplasm } \\
n(\%)\end{array}$ & $\begin{array}{c}\text { Nucleus } \\
n(\%)\end{array}$ & $p$-value \\
\hline $\begin{array}{l}\text { CD-3 } \\
\text { (T-lymphocytes) }\end{array}$ & L-PRF & $8(80)$ & $2(20)$ & 0.075 \\
CD-15 & T-PRF & $9(90)$ & $1(10)$ & $1(10)$ \\
(neutrophils) & T-PRF & $8(80)$ & $2(20)$ & 0.075 \\
CD-20 & L-PRF & $8(80)$ & $2(20)$ & 0.075 \\
(B-lymphocytes) & T-PRF & $9(90)$ & $1(10)$ & \\
CD-34 & L-PRF & $10(100)$ & $0(0)$ & $<0.001^{*}$ \\
(stem cells) & T-PRF & $6(60)$ & $4(40)$ & \\
CD-61 & L-PRF & $6(60)$ & $4(40)$ & $0.003^{*}$ \\
(platelets) & T-PRF & $8(80)$ & $2(20)$ & \\
CD-163 & L-PRF & $9(90)$ & $1(10)$ & 0.075 \\
(monocytes) & T-PRF & $8(80)$ & $2(20)$ & \\
\hline
\end{tabular}

* statistically significant.
- the cellular pattern - independent or clustered;

- the labeling index percentage ${ }^{21}$ calculated as the total number of stained cells / $500 \times 100$.

\section{Statistical analysis}

All the data from the slides was tabulated using the Microsoft Excel ${ }^{\circledR}$ software (Microsoft Corporation, Redmond, USA), whereas the analysis was performed using the IBM SPSS Statistics for Windows v. 22 software (IBM Corp., Armonk, USA). The $\chi^{2}$ test was performed to find any correlation between L-PRF and T-PRF in terms of localization, cellular distribution, the positivity of staining, and the cellular pattern. The independent $t$-test was performed for the evaluation of the positively stained cells and the labeling index percentage.

\section{Results}

Regarding the localization of staining in both the L-PRF and T-PRF groups, all IHC markers showed predominant cytoplasmic staining when compared to the nucleus. The results were statistically significant for the CD-61 marker $(p=0.003)$ for platelets in the T-PRF group and for the CD-34 marker $(p<0.001)$ for stem cells in the L-PRF group. The rest of the markers showed nonsignificant results (Table 3 ). 
In terms of cellular distribution, T-PRF showed a stronger positivity than L-PRF for the CD-3, CD-20 and CD-61 markers; the difference was statistically significant $(p<0.001)$. The staining of the CD-15 and CD-163 markers was moderately positive, and CD-34 showed mildly positive cells in both the L-PRF and T-PRF groups, but the results were not statistically significant (Table 4).

Regarding the cellular patterns, all antibody markers in both the T-PRF and L-PRF groups showed predominantly clustered rather than independent patterns, but the values were statistically significant $(p<0.001)$

Table 4. Cellular distribution shown with the IHC markers

\begin{tabular}{|c|c|c|c|c|c|}
\hline \multirow[b]{2}{*}{ IHC marker } & \multirow[b]{2}{*}{$\begin{array}{l}\text { Study } \\
\text { group }\end{array}$} & \multicolumn{3}{|c|}{$\begin{array}{l}\text { Cell distribution } \\
n(\%)\end{array}$} & \multirow[b]{2}{*}{$p$-value } \\
\hline & & $\begin{array}{c}\text { mildly } \\
\text { positive } \\
(0-25 \%)\end{array}$ & $\begin{array}{c}\text { moderately } \\
\text { positive } \\
(26-75 \%)\end{array}$ & \begin{tabular}{|c|} 
strongly \\
positive \\
$(76-100 \%)$
\end{tabular} & \\
\hline \multirow{2}{*}{$\begin{array}{l}\text { CD-3 } \\
\text { (T-lymphocytes) }\end{array}$} & L-PRF & $5(50)$ & $5(50)$ & $0(0)$ & \multirow{2}{*}{$<0.001^{*}$} \\
\hline & T-PRF & $0(0)$ & $0(0)$ & $10(100)$ & \\
\hline \multirow{2}{*}{$\begin{array}{l}\text { CD-15 } \\
\text { (neutrophils) }\end{array}$} & L-PRF & $0(0)$ & $10(100)$ & $0(0)$ & \multirow{2}{*}{0.0849} \\
\hline & T-PRF & $0(0)$ & $10(100)$ & $0(0)$ & \\
\hline \multirow{2}{*}{$\begin{array}{l}\text { CD-20 } \\
\text { (B-lymphocytes) }\end{array}$} & L-PRF & $0(0)$ & $10(100)$ & $0(0)$ & \multirow{2}{*}{$<0.001^{*}$} \\
\hline & T-PRF & $0(0)$ & $0(0)$ & $10(100)$ & \\
\hline \multirow{2}{*}{$\begin{array}{l}\text { CD-34 } \\
\text { (stem cells) }\end{array}$} & L-PRF & 10 (100) & $0(0)$ & $0(0)$ & \multirow{2}{*}{1.000} \\
\hline & T-PRF & $10(100)$ & $0(0)$ & $0(0)$ & \\
\hline \multirow{2}{*}{$\begin{array}{l}\text { CD-61 } \\
\text { (platelets) }\end{array}$} & L-PRF & $0(0)$ & $10(100)$ & $0(0)$ & \multirow{2}{*}{$<0.001^{*}$} \\
\hline & T-PRF & $0(0)$ & $0(0)$ & $10(100)$ & \\
\hline \multirow{2}{*}{$\begin{array}{l}\text { CD-163 } \\
\text { (monocytes) }\end{array}$} & L-PRF & $0(0)$ & $10(100)$ & $0(0)$ & \multirow{2}{*}{0.611} \\
\hline & T-PRF & $0(0)$ & $10(100)$ & $0(0)$ & \\
\hline
\end{tabular}

* statistically significant.

Table 5. Cell patterns shown with the IHC markers

\begin{tabular}{|c|c|c|c|c|}
\hline \multirow[t]{2}{*}{ IHC marker } & \multirow{2}{*}{$\begin{array}{l}\text { Study } \\
\text { group }\end{array}$} & \multicolumn{2}{|c|}{$\begin{array}{c}\text { Cell pattern } \\
n(\%)\end{array}$} & \multirow[t]{2}{*}{$p$-value } \\
\hline & & independent & clustered & \\
\hline \multirow{2}{*}{$\begin{array}{l}\text { CD-3 } \\
\text { (T-lymphocytes) }\end{array}$} & L-PRF & $2(20)$ & $8(80)$ & \multirow{2}{*}{0.862} \\
\hline & T-PRF & $2(20)$ & $8(80)$ & \\
\hline \multirow{2}{*}{$\begin{array}{l}\text { CD-15 } \\
\text { (neutrophils) }\end{array}$} & L-PRF & $8(80)$ & $2(20)$ & \multirow{2}{*}{$<0.001^{*}$} \\
\hline & T-PRF & $3(30)$ & $7(70)$ & \\
\hline \multirow{2}{*}{$\begin{array}{l}\text { CD-20 } \\
\text { (B-lymphocytes) }\end{array}$} & L-PRF & $3(30)$ & $7(70)$ & \multirow{2}{*}{$<0.001^{*}$} \\
\hline & T-PRF & $1(10)$ & $9(90)$ & \\
\hline \multirow{2}{*}{$\begin{array}{l}\text { CD-34 } \\
\text { (stem cells) }\end{array}$} & L-PRF & $4(40)$ & $6(60)$ & \multirow{2}{*}{0.182} \\
\hline & T-PRF & $3(30)$ & $7(70)$ & \\
\hline \multirow{2}{*}{$\begin{array}{l}\text { CD-61 } \\
\text { (platelets) }\end{array}$} & L-PRF & $4(40)$ & $6(60)$ & \multirow{2}{*}{0.182} \\
\hline & T-PRF & $3(30)$ & $7(70)$ & \\
\hline \multirow{2}{*}{$\begin{array}{l}\text { CD-163 } \\
\text { (monocytes) }\end{array}$} & L-PRF & $3(30)$ & $7(70)$ & \multirow{2}{*}{0.142} \\
\hline & T-PRF & $2(20)$ & $8(80)$ & \\
\hline
\end{tabular}

* statistically significant. only for CD-15 (an independent pattern) in the L-PRF group and for CD-20 (a clustered pattern) in the T-PRF group (Table 5). The mean $(M)$ and standard deviation $(S D)$ values of the positively stained cells in the T-PRF and L-PRF groups were statistically significant $(p=0.000)$ for the CD-3, CD-20 and CD-61 antibodies (Table 6 ). The mean labeling index percentage values for all markers were higher for the T-PRF group than for the L-PRF group, but the only statistically significant differences $(p<0.001)$ were obtained for the CD-3, CD-20 and CD-61 markers (Table 7).

Table 6. Mean (M) and standard deviation (SD) values of the positively stained cells

\begin{tabular}{|l|c|c|c|c|}
\multicolumn{1}{|c|}{ IHC marker } & $\begin{array}{c}\text { Study } \\
\text { group }\end{array}$ & $\begin{array}{c}\text { Slides } \\
N\end{array}$ & M \pm SD & $p$-value \\
\hline $\begin{array}{l}\text { CD-3 } \\
\text { (T-lymphocytes) }\end{array}$ & L-PRF & 10 & $211.70 \pm 69.32$ & 0.075 \\
CD-15 & T-PRF & 10 & $392.40 \pm 8.69$ & \\
(neutrophils) & L-PRF & 10 & $234.50 \pm 41.33$ & 0.075 \\
CD-20 & T-PRF & 10 & $272.00 \pm 50.23$ & \\
(B-lymphocytes) & L-PRF & 10 & $231.00 \pm 65.61$ & 0.075 \\
CD-34 & T-PRF & 10 & $392.30 \pm 8.78$ & \\
(stem cells) & L-PRF & 10 & $99.90 \pm 12.91$ & $<0.001^{*}$ \\
CD-61 & T-PRF & 10 & $96.30 \pm 15.96$ & \\
(platelets) & L-PRF & 10 & $309.60 \pm 31.17$ & $0.003^{*}$ \\
CD-163 & T-PRF & 10 & $390.40 \pm 19.11$ & \\
(monocytes) & L-PRF & 10 & $251.50 \pm 83.37$ & 0.075 \\
\hline
\end{tabular}

* statistically significant.

Table 7. Mean (M) and standard deviation (SD) values of the labeling index percentage of the positively stained cells

\begin{tabular}{ll|l|l|l|}
\multicolumn{1}{|c|}{ IHC marker } & $\begin{array}{l}\text { Study } \\
\text { group }\end{array}$ & $N$ & $\begin{array}{c}\text { Labeling index } \\
\text { percentage [\%] } \\
M \pm \text { SD }\end{array}$ & $p$-value \\
\hline $\begin{array}{l}\text { CD-3 } \\
\text { (T-lymphocytes) }\end{array}$ & L-PRF & 10 & $44.38 \pm 13.02$ & $<0.001^{*}$ \\
CD-15 & T-PRF & 10 & $78.48 \pm 1.74$ & \\
(neutrophils) & L-PRF & 10 & $46.89 \pm 8.77$ & 0.102 \\
CD-20 & T-PRF & 10 & $54.40 \pm 10.05$ & \\
(B-lymphocytes) & T-PRF & 10 & $45.44 \pm 13.68$ & $<0.001^{*}$ \\
CD-34 & L-PRF & 10 & $78.46 \pm 1.76$ & 0.718 \\
(stem cells) & T-PRF & 10 & $19.76 \pm 2.63$ & \\
CD-61 & L-PRF & 10 & $60.80 \pm 5.44$ & $<0.001^{*}$ \\
(platelets) & T-PRF & 10 & $78.08 \pm 3.82$ & \\
CD-163 & L-PRF & 10 & $47.89 \pm 15.73$ & 0.119 \\
(monocytes) & T-PRF & 10 & $58.50 \pm 12.42$ & \\
\hline
\end{tabular}

* statistically significant. 


\section{Discussion}

Tissue engineering plays an important role in predictable periodontal regeneration procedures. ${ }^{3}$ The PRF membranes act as scaffolds for enmeshing various cells, including white blood cells, platelets, progenitor cells, and red blood cells, which release many growth factors and cytokines that create a transient inflammatory condition, inducing the formation of new periodontal tissues. ${ }^{22,23}$ The PRF clots are autologous substances and do not require any additional anticoagulants for their preparation; they are easy to use and can be prepared at chairside in minimal time, so they can yield good results when used in combination with various biomaterials. ${ }^{3}$ In the present study, as standard protocols were followed during the preparation of the L-PRF and T-PRF clots, the centrifugation rates were normal and the obtained clots had a mature fibrin meshwork.

In the present study, the maximum cell staining occurred in the cytoplasm rather than in the nucleus in both study groups. This was in accordance with the study conducted by Ghanaati et al. ${ }^{9}$ It means a higher number of active cells, which could possibly lead to an increased release of growth factors and cytokines, resulting in the stimulation of cells to produce new periodontal tissues. In the present study, cellular distribution showed a significant $76-100 \%$ staining of T-lymphocytes, B-lymphocytes and platelets in the T-PRF group, whereas in both groups, a nonsignificant distribution of $26-75 \%$ staining was observed for neutrophils and monocytes, and 0-25\% for stem cells. However, a study by Ghanaati et al. showed mixed cellular distribution, in which the maximum T-lymphocyte distribution was in the buffy coat, neutrophils covered $2 / 3$ of the entire surface of the clot, platelets were distributed throughout the clot, and the rest of the cells covered $<30 \%$ of the entire surface of the clot in both the A-PRF and L-PRF groups. ${ }^{9}$ These variations in the localization of cell staining and in cellular distribution might be due to differences in the sedimentation rates, in the density, size and shape of the cells, and in centrifugation conditions.

In the present study, all cellular markers in both groups showed a predominantly clustered pattern, but the only statistically significant differences were noted among neutrophils and B-lymphocytes. This was in accordance with Tunali et al., who stated that even though L-PRF and T-PRF shared a similar structure, a thicker fibrin mesh was found in T-PRF, which entrapped a greater number of cells in the fibrin clot. ${ }^{12}$ This might be due to an increased centrifugation time and a better hemocompatibility of titanium, which led to the formation of a thicker fibrin mesh than in the L-PRF group and triggered more cells to accumulate in the fibrin mesh.

In the present study, platelets were significantly higher in the T-PRF group than in the L-PRF group in most respects, such as the localization of staining, cellular distri- bution, the mean cell count, and the labeling index percentage, whereas the values regarding the cell pattern were nonsignificant in both groups; still, the platelets were distributed on the entire surface of the clot. This is in accordance with Ghanaati et al., where platelets were also distributed on the entire surface of the clot. ${ }^{9}$ This might be due to a low centrifugation speed over an extended time. Still, in the present study, apart from an extended centrifugation time, an increased entrapment of platelets in the fibrin mesh might be due to a better activation of platelets by $\mathrm{TiO}_{2}$ passivated within titanium tubes, as stated by Tunalı et al. ${ }^{12}$ Platelets play an important role in the stimulation of the adjacent cells, such as neutrophils/monocytes and other cells, by altering the immune response, and releasing various cytokines, growth factors ${ }^{5}$ and adhesion molecules (vitronectin, fibronectin, P-selectin and von Willebrand's factor ${ }^{24}$ ). These stimulate adjacent progenitor cells, thus releasing bone morphogenetic proteins and helping in new bone formation and healing. ${ }^{25}$

In their recent study, Choukroun and Ghanaati postulated that low-speed centrifugation increases the number of neutrophils, platelets and growth factors in injectable PRF. ${ }^{26}$ While counting neutrophils and platelets, they observed higher counts of cells with a lower relative centrifugal force. ${ }^{26}$ In contrast, the present study used a standard number of rotations per minute and an extended centrifugation time, but the results were better than those reported by Choukroun and Ghanaati, and showed nonsignificantly higher neutrophil counts for the mean cell count and the labeling index percentage in the T-PRF group than in the L-PRF group, whereas both groups showed similar cell distribution. The presence of neutrophils in PRF helps to prevent the clot contamination from bacteria and stimulates the adjacent cells at the surgical site by releasing cytokines, which are important in the regeneration of periodontal tissues.

Monocytes are cells that act as the second line of defense after neutrophils; they are chemotactically drawn to the site of inflammation and transform themselves into tissue histiocytes to regulate their phagocytic activity. ${ }^{27}$ They secrete several growth factors, cause changes in angiogenesis, bone formation and tissue response, and guide regeneration and cell proliferation, necessary for rapid wound repair, healing and scar formation. They also contribute to the stimulation of lymphocytes, which help in periodontal regeneration. ${ }^{28-30}$

B-lymphocytes are the $2^{\text {nd }}$ type of lymphocytes that act as powerful modulators of tissue regeneration. They also modulate the immune response by converting into plasma cells and presenting antigens to $\mathrm{T}$ cells. These help in regeneration by releasing pro- and anti-inflammatory cytokines. ${ }^{31}$ Boyce et al. demonstrated that initially B-lymphocytes were not identified, as they accumulate gradually during the natural healing process, but with ongoing research they identified B-lymphocytes on the $5^{\text {th }}$ day of the healing process. ${ }^{32}$ Boyce et al. posited that 
with increased B-lymphocyte counts there is an increased secretion of interleukin 6, promoting wound healing and periodontal regeneration. ${ }^{32}$

In the present study, significantly higher mean cell counts and labeling index percentage values were observed for T-lymphocytes, B-lymphocytes and platelets in the T-PRF group. This was in agreement with a previous histochemical study conducted by Chatterjee et al., who concluded that T-PRF had a better fibrin mesh, which contributed to a better cellular entrapment with higher cell counts. ${ }^{33}$ The present study is also compatible with a study conducted by Mitra et al., who concluded that T-PRF had a denser fibrin mesh and cellularity than L-PRF. ${ }^{34}$ On the other hand, contrasting results were reported by Yajamanya et al., who concluded that L-PRF had a thicker fibrin mesh with good cellular entrapment in young individuals as opposed to elderly subjects. ${ }^{35}$

In the present study, the cell distribution (mild positivity), mean cell count and labeling index of stem cells showed no significant differences between the L-PRF and T-PRF groups. This was in accordance with a study conducted by Ghanaati et al., in which stem cells covered no more than $30 \%$ of the clot surface. ${ }^{9}$ In the present study, stem cells were obtained from the blood clot, and hence were thought to be of hematopoietic origin. Ogawa et al. stated that hematopoietic stem cells are pluripotent in nature and can differentiate into most types of cells. ${ }^{36}$ Thus, they are unique assets of PRF, differentiating into various types of cells depending on requirements, such as the regeneration of bone, periodontal ligament or cementum at the site of interest, making them good candidates for therapeutic vehicles. They also have effects as immune modulators. ${ }^{37-39}$

\section{Conclusions}

To our knowledge, this study was the first to compare the labeling index percentage of T-PRF and L-PRF using IHC markers.

The limitations of the study might be the small sample size, and the costs of titanium tubes and the antibody markers used. In addition, we did not assess the variations in centrifugation speed and duration. However, within the limitations of this study, it can be concluded that T-PRF has a significantly better cellular distribution for T-lymphocytes, B-lymphocytes, platelets, neutrophils, and monocytes than L-PRF. Due to this extra edge of T-PRF, it emerged as a novel entity, and can be used as a better alternative to L-PRF in the field of periodontal regeneration. However, progenitor cells, which are required for the formation of new periodontal tissues from differentiated cells, are present in very similar quanitites in both T-PRF and L-PRF. Further interventional studies with long-term follow-ups are required to determine the extent of periodontal regeneration.

\section{ORCID iDs}

Hirak Shubhra Bhattacharya (1) https://orcid.org/0000-0001-8518-0597 Shiva Shankar Gummaluri (1) https://orcid.org/0000-0003-3892-7332 Madhusudan Astekar (1) https://orcid.org/0000-0002-6927-411X Ram Kumar Gummaluri (1) https://orcid.org/0000-0002-8354-0349

\section{References}

1. Chen FM, Jin Y. Periodontal tissue engineering and regeneration: Current approaches and expanding opportunities. Tissue Eng Part $B$ Rev. 2010;16(2):219-255.

2. Dzobo K, Thomford NE, Senthebane DA, et al. Advances in regenerative medicine and tissue engineering: Innovation and transformation of medicine. Stem Cells Int. 2018;2018:2495848.

3. Agrawal AA. Evolution, current status and advances in application of platelet concentrate in periodontics and implantology. World J Clin Cases. 2017;5(5):159-171.

4. Choukroun J, Adda F, Schoeffer C, Vervelle A. PRF: An opportunity in perio-implantology [in French]. Implantodontie. 2000;42:55-62.

5. Dohan DM, Choukroun J, Diss A, et al. Platelet-rich fibrin (PRF): A second-generation platelet concentrate. Part I: Technological concepts and evolution. Oral Surg Oral Med Oral Pathol Oral Radiol Endod. 2006;101(3):e37-e44.

6. Agarwal A, Gupta ND, Jain A. Platelet-rich fibrin combined with decalcified freeze-dried bone allograft for the treatment of human intrabony periodontal defects: A randomized split mouth clinical trail. Acta Odontol Scand. 2016;74(1):36-43.

7. Pradeep AR, Nagpal K, Karvekar S, Patnaik K, Naik SB, Guruprasad CN. Platelet-rich fibrin with $1 \%$ metformin for the treatment of intrabony defects in chronic periodontitis: A randomized controlled clinical trial. J Periodontol. 2015;86(6):729-737.

8. Verma UP, Yadav RK, Dixit M, Gupta A. Platelet-rich fibrin: A paradigm in periodontal therapy - a systematic review. J Int Soc Prev Community Dent. 2017;7(5):227-233.

9. Ghanaati $S$, Booms P, Orlowska A, et al. Advanced platelet-rich fibrin: A new concept for cell-based tissue engineering by means of inflammatory cells. J Oral Implantol. 2014;40(6):679-689.

10. Dohan Ehrenfest DM, de Peppo GM, Doglioli P, Sammartino G. Slow release of growth factors and thrombospondin-1 in Choukroun's platelet-rich fibrin (PRF): A gold standard to achieve for all surgical platelet concentrates technologies. Growth Factors. 2009;27(1):63-69.

11. O'Connell SM. Safety issues associated with platelet-rich fibrin method. Oral Surg Oral Med Oral Pathol Oral Radiol Endod. 2007;103(5):587-593.

12. Tunalı M, Özdemir H, Küçükodacı Z, Akman S, Fıratlı E. In vivo evaluation of titanium-prepared platelet-rich fibrin (T-PRF): A new platelet concentrate. Brit J Oral Maxillofac Surg. 2013;51(5):438-443.

13. Tunalı $M$, Özdemir $H$, Küçükodacı $Z$, et al. A novel platelet concentrate for guided bone regeneration: Titanium-prepared plateletrich fibrin. Biomed Res Int. 2014;2014:209548.

14. Duan X, Lin Z, Lin X, et al. Study of platelet-rich fibrin combined with rat periodontal ligament stem cells in periodontal tissue regeneration. J Cell Mol Med. 2018;22(2):1047-1055.

15. Di Liddo R, Bertalot $T$, Borean A, et al. Leucocyte and platelet-rich fibrin: A carrier of autologous multipotent cells for regenerative medicine. J Cell Mol Med. 2018;22(3):1840-1854.

16. He L, Lin Y, Hu X, Zhang Y, Wu H. A comparative study of plateletrich fibrin (PRF) and platelet-rich plasma (PRP) on the effect of proliferation and differentiation of rat osteoblasts in vitro. Oral Surg Oral Med Oral Pathol Oral Radiol Endod. 2009;108(5):707-713.

17. Huang FM, Yang SF, Zhao JH, Chang YC. Platelet-rich fibrin increases proliferation and differentiation of human dental pulp cells. $J$ Endod. 2010;36(10):1628-1632.

18. Mazor Z, Horowitz RA, Del Corso M, Prasad HS, Rohrer MD, Dohan Ehrenfest DM. Sinus floor augmentation with simultaneous implant placement using Choukroun's platelet-rich fibrin as the sole grafting material: A radiologic and histologic study at 6 months. J Periodontol. 2009;80(12):2056-2064.

19. Duraiyan J, Govindarajan R, Kaliyappan K, Palanisamy M. Applications of immunohistochemistry. J Pharm Bioallied Sci. 2012;4(Suppl 2): S307-S309.

20. Bancroft JD, Cook H, Turner D. Manual of Histological Techniques and Their Diagnostic Application. $3^{\text {rd }}$ ed. Philadelphia, USA: Churchill Livingstone/Elsevier Health Sciences; 1996:986-998. 
21. Alrani D, Niranjan KC, Sarathy NA. Assessment of proliferative index between the tumor margin, center of tumor, and the invasive tumor front of oral squamous cell carcinoma with the help of Mcm-2: An immunohistochemical study. Appl Immunohistochem Mol Morphol. 2020;28(1):30-35.

22. Choukroun J, Diss A, Simonpieri A, et al. Platelet-rich fibrin (PRF): A second-generation platelet concentrate. Part IV: Clinical effects on tissue healing. Oral Surg Oral Med Oral Pathol Oral Radiol Endod. 2006;101(3):e56-e60.

23. Arora S, Agnihotri N. Platelet derived biomaterials for therapeutic use: Review of technical aspects. Indian J Hematol Blood Transfus. 2017;33(2):159-167.

24. Eppley BL, Pietrzak WS, Blanton M. Platelet-rich plasma: A review of biology and applications in plastic surgery. Plast Reconstr Surg. 2006;118(6):147e-159e.

25. Jenne CN, Urrutia R, Kubes P. Platelets: Bridging hemostasis, inflammation, and immunity. Int J Lab Hematol. 2013;35(3):254-261.

26. Choukroun J, Ghanaati S. Reduction of relative centrifugation force within injectable platelet-rich-fibrin (PRF) concentrates advances patients' own inflammatory cells, platelets and growth factors: The first introduction to the low speed centrifugation concept. Eur J Trauma Emerg Surg. 2018;44(1):87-95.

27. Soltan M, Rohrer MD, Prasad HS. Monocytes: Super cells for bone regeneration. Implant Dent. 2012;21(1):13-20.

28. Tan KW, Chong SZ, Wong FH, et al. Neutrophils contribute to inflammatory lymphangiogenesis by increasing VEGF-A bioavailability and secreting VEGF-D. Blood. 2013;122(22):3666-3677.

29. Ekström K, Omar O, Granéli C, Wang X, Vazirisani F, Thomsen P. Monocyte exosomes stimulate the osteogenic gene expression of mesenchymal stem cells. PloS One. 2013;8(9):e75227.

30. Maciel J, Oliveira Ml, Colton E, et al. Adsorbed fibrinogen enhances production of bone- and angiogenic-related factors by monocytes/macrophages. Tissue Eng Part A. 2014;20(1-2):250-263.

31. Sîrbulescu RF, Boehm CK, Soon E, et al. Mature B cells accelerate wound healing after acute and chronic diabetic skin lesions. Wound Repair Regen. 2017;25(5):774-791.

32. Boyce DE, Jones WD, Ruge F, Harding KG, Moore K. The role of lymphocytes in human dermal wound healing. Br J Dermatol. 2000;143(1):59-65.

33. Chatterjee A, Debnath K, Ali MM, Babu C, Gowda PL. Comparative histologic evaluation of titanium platelet-rich fibrin and platelet-rich fibrin in hypertensive and smoker participants: A cell cytology study. $J$ Indian Soc Periodontol. 2017;21(3):195-200.

34. Mitra DK, Potdar PN, Prithyani SS, Rodrigues SV, Shetty GP, Talati MA. Comparative study using autologous platelet-rich fibrin and titanium prepared platelet-rich fibrin in the treatment of infrabony defects: An in vitro and in vivo study. J Indian Soc Periodontol. 2019;23(6):554-561.

35. Yajamanya SR, Chatterjee A, Babu CN, Karunanithi D. Fibrin network pattern changes of platelet-rich fibrin in young versus old age group of individuals: A cell block cytology study. J Indian Soc Periodontol. 2016;20(2):151-156.

36. Ogawa M, LaRue AC, Mehrotra M. Hematopoietic stem cells are pluripotent and not just "hematopoietic". Blood Cells Mol Dis. 2013;51(1):3-8

37. Lim WF, Inoue-Yokoo T, Tan KS, Lai MI, Sugiyama D. Hematopoietic cell differentiation from embryonic and induced pluripotent stem cells. Stem Cell Res Ther. 2013;4(3):71-82.

38. Nicolaidou V, Wong MM, Redpath AN, et al. Monocytes induce STAT3 activation in human mesenchymal stem cells to promote osteoblast formation. PloS One. 2012;7(7):e39871.

39. Wang L, Zhao Y, Shi S. Interplay between mesenchymal stem cells and lymphocytes: Implications for immunotherapy and tissue regeneration. J Dent Res. 2012;91(11):1003-1010. 